\title{
Students' Adoption of Social Networks as Environments for Learning and Teaching: The Case of the Facebook
}

\author{
http://dx.doi.org/10.3991/ijet.v9i8.3722 \\ W. Daher ${ }^{1,2}$ \\ ${ }^{1}$ An-Najah National University, Nablus, Palestine \\ ${ }^{2}$ Al-Qasemic Academic College of Education, Baqa, Israel
}

\begin{abstract}
Little is known about the conditions and consequences of using the Facebook in learning. This research attempts to describe such conditions and consequences when teachers experiment using it as students in a second degree course. Fifteen students/teachers aged from 24 to 53 years old participated in the course in which they were required to attend mathematical Facebook sites. The research findings arrived at using the grounded theory show that the conditions which affected the teachers/students' work in the Facebook were: (1) causal conditions: the course's requirement; (2) intervening conditions: the participant's image of the Facebook, the participant's work characteristics and the participant's competence in computers and the internet; (3) contextual conditions: The site's subject and the environment's characteristics or conditions. These conditions influenced students' learning actions and interactions in the Facebook, especially their level of participation. The actions/interactions of the participants, together with the various conditions influenced the consequences of students' educational work in the social networking site. These consequences varied, starting from discovering how to utilize the Facebook for teaching and being aware of the advantages/ disadvantages of doing so, to proceeding with the use of the Facebook in contexts other than those being suggested in the course.
\end{abstract}

Index Terms - teachers, students, students' adoption, social networks, Facebook

\section{INTRODUCTION}

In recent years we witness a rapid increase in the use of web 2.0 technology as an environment that facilitates collaboration and participation in information, which occurs due to the ability of the user to add and edit the information space [1]. Some of the popular web 2.0 applications are wikis, blogs, the Facebook, MySpace, twitter, etc. Ref. [2] says that the web 2.0 technology, which includes the blog, the wiki, RSS, social bookmarking, and other new applications, are becoming more popular in the classrooms in all educational levels. Ref. [2] describes these applications as supporting interaction, community building, knowledge building, creating content and changing it. Ref. [3] describes the affordances of the social software tools: Connectivity and social rapport, collaborative information discovery and sharing, content creation, knowledge and information aggregation and content modification. These affordances are expected to encourage teachers to use the social software tools in the classrooms.
The web 2.0 applications which attracted the attention of researchers from the beginning, regarding their use in education, were the wiki and the blog. Regarding the blog, Ref. [1] pointed at the blog as the most popular tool which educators from various fields used for peer discussion, for sharing preliminary results or requiring help in the context of experimental subjects. Researchers examined the use of blogs in composition and language classes, for example Ref. [4] examined students' use of blogs and paper for writing composition and found that when using blogs, students increased their writing by $50 \%$. Further, the length of the values in blogs was about $30 \%$ longer than on paper. All the participants expressed preference for writing in blogs. Reasons for this preference were: ease of use, having time to write a careful answer, the ability to clarify an idea or position, the ability to publish to an audience, the ability to express an opinion without criticism, and the ability to influence in one's own space.

Regarding wiki, researchers pointed at the site as encouraging interaction, collaboration and knowledge building. Ref. [5] studied preservice teachers' interactions in a wiki environment regarding geometry lessons prepared by other preservice teachers. He found that through these interactions the preservice teachers developed various types of teachers' knowledge, especially their content and pedagogic content knowledge. Ref. [6] suggested the wiki as a tool which students could use not only for writing, but also for building public knowledge in schools. Ref. [7] described the wiki environment as a type of strong software which supports collaborative applications and learning activities.

The Facebook is considered a social networking site which attracts a growing number of teenagers everyday. Researchers examined the use of the Facebook in education and pointed at the following educational uses made of it by educators: an environment for managing teaching ([8] and social events at educational institutions [9], an environment for different types of educational interactions ([10], [11], [12]), an environment for motivating students and influencing positively their affect ([13], [14], [15])) and an environment for teaching and learning new topics ([16], [17]). A more detailed description of these researches follows.

Some educators tried to utilize the Facebook as a tool for managing their teaching and their students' learning. Ref. [18] described the experience of grade one teacher who used the Facebook in her teaching. The teacher used the Facebook to update the students' parents regarding 
what happens during the day in her class, where the updating was done primarily by the students themselves. The teacher also planned to use the following year the Facebook 'notes' feature for students to publish their work.

Universities use the Facebook to plan social events, and university students use it in order to join university groups and to keep up with what is happening socially with peers currently at the university. In addition university students use the Facebook to make social links with others at university, thus enriching their university socialization process [9].

Ref. [12] says that the Facebook increases students and student-teacher interactions and helps the teacher to communicate with the students outside the classroom regarding tasks, future events, useful links, and assignments. The students can use the Facebook to communicate with peers regarding questions about tasks and exams, or regarding collaboration on group assignments and projects in an online environment. Further, one research found that students were comfortable to be with their instructors in the Facebook [11], while another research found that thirty nine percent of the academic students who participated in the research wanted to have online discussion with their instructors in the Facebook [10].

Another issue which was studied regarding the educational influence of the Facebook is the affective aspect of students' learning. Ref. [14] and Ref. [15] reported that students who had access to teachers' websites containing self-disclosed information reported a high level of motivation and affective learning. Further, this access made students develop positive attitudes towards the teacher and the course. These findings point that the Facebook, if used properly in education, can be a rich source for motivational and affective learning.

Regarding teaching and learning new topics in the Facebook, Ref. [16] suggest the feature 'group' in the Facebook to be used in the language classroom; specifically they suggest that language variation and other important linguistic and cultural issues (for example linguistic characteristics associated with a certain geographical area) can easily be presented in Facebook groups. Ref. [17] found that students believed the Facebook could be utilized as an online environment to facilitate the learning of English. The authors advise that language teachers have to integrate in the Facebook educational projects with predetermined learning objectives and outcomes for the language learning experience to become meaningful.

Ref. [17] explored the use of the Facebook to support business education students enrolled in education degrees at Queensland University of Technology. A group page was created in the Facebook to examine the students' experiences and behaviors during their teaching practicum placements. The posts to the discussion topics in the group were coded into five broad themes: excitement, problem, joke, solution, and other. The Other theme included posts that were associated with affective communication such as group reinforcement, encouragement and support. This research of Ref. [17] implies that the Facebook could be used to support the cognitive and the affective aspects of learning. The current research wants to examine the conditions and consequences of university students' adoption of the Facebook, as a tool for teaching and learning. This will be done using the grounded theory model [19] which highlights the various conditions leading to social and educational phenomena, as well as their consequences. This model will be described in the methodology section.

\section{RESEARCH RATIONALE AND GOALS}

The Facebook is becoming an environment for educational transactions. Students and teachers are beginning to use it for various educational targets. The researches described above examined the ways students and teachers have been using the Facebook in learning and teaching. Few researches examined the conditions that influence students' and teachers' use of the Facebook and the consequences of this use. This research attempts to do so. The results of the research will provide educators with information about the various conditions which influence students' and teachers' educational use of the Facebook and the consequences of such use. This information would help teachers know when and how to integrate social networks, as the Facebook, in students' learning.

\section{RESEARCH QUESTIONS}

1. What are the conditions that influence students' and teachers' educational use of a social network, as the Facebook?

2. What are the consequences of students' and teachers' educational use of a social network, as the Facebook?

\section{RESEARCH METHODOLOGY}

\section{A. Research setting and participants:}

The research participants were fifteen second degree students who participated in the course "Computers in Education" in the faculty of educational sciences in AnNajah National University. These students were middle and high school teachers and supervisors aged from 24 to 53 years old. One of the course modules was Web 2.0 which included wikis, blogs and the Facebook. The students in the Facebook task were required to be friends with one Facebook character called "Al-Khwarizmi", to be fans of one Facebook group called "Al-Khayyam", and to attend one Facebook page called "The Golden Ratio". They were directed to participate in the social, cultural and mathematical talk occurring in the three Facebook sites.

\section{B. Data collecting tools:}

The fifteen students were interviewed regarding their work in the three Facebook sites. The interviews were semi-structured and included questions that probed the participants' experience in the Facebook, the conditions that influence their use of the Facebook for their learning and the consequences of that use.

\section{Data analysis tools:}

Coding the participants' interviews:

The first two stages of the grounded theory [19] were used to analyze the data regarding students' experience in the Facebook and the conditions that influenced their use of the Facebook for learning. These stages were:

Open coding: putting together data expressions or sentences that imply a condition that influences the students' use of the Facebook for their learning, for example, putting together all expressions or sentences that imply the condition for putting a mathematical question in the Facebook. 
Axial coding: comparing expressions or sentences within each previously built category. This would give rise to sub-categories. Let's take for example the category 'putting a mathematical question in the Facebook', comparing expressions or sentences in this category may give rise to the subcategories: putting a mathematical question to have an advice regarding its solution, putting a mathematical question as a task for the students, putting a mathematical question as an initiator to the new lesson.

\section{Relevance of the data analysis to the setting and theme of the study}

The objective of the study was to find the conditions for using the Facebook for learning and teaching. The use of the grounded theory to identify the conditions and consequences of an educational phenomenon is reported in the literature, for example, Ref. [20] used the grounded theory approach to find the conditions and consequences of middle school learning of mathematics while using the cellular phones.

\section{FINDINGS}

The findings describe the characteristics of the students participating in the research, the conditions influencing their educational use of the Facebook and the consequences of that use. We will divide the participants across their educational experience, specialty and work's type.

We first describe the characteristics, conditions and Facebook educational work of the six experienced educators.

Table I describes the division of the six educationally experienced participants (work experience more than ten years) across their other characteristics.

Akram: An experienced teacher in mathematics, as well as in computers and internet. Akram is 46 years old and has been a middle and high school teacher of mathematics for 20 years. Previously He had a negative idea of the Facebook though he worked with different internet applications like the wiki and the Webquest. After participating moderately in the three mathematical Facebook sites he suggested the sites for his students in order to find out how they can benefit mathematically from them.

Salem: An experienced teacher in science. He is experienced in computers and internet too, but did not have a Facebook account before participating in the course. Salem is 35 years old and has been a middle school teacher

TABLE I.

THE EDUCATIONALLY EXPERIENCED PARTICIPANTS

\begin{tabular}{|c|c|c|c|c|c|}
\hline \multirow{2}{*}{} & \multicolumn{2}{|c|}{ Teachers } & \multicolumn{2}{c|}{ Not teachers } \\
\cline { 2 - 5 } & $\begin{array}{c}\text { Math } \\
\text { majors }\end{array}$ & $\begin{array}{c}\text { Non- } \\
\text { math } \\
\text { majors }\end{array}$ & \multicolumn{2}{|c|}{ Math majors } & $\begin{array}{c}\text { Non- } \\
\text { math } \\
\text { majors }\end{array}$ \\
\cline { 3 - 6 } & & Akram & $\begin{array}{c}\text { Work } \\
\text { related to } \\
\text { math }\end{array}$ & $\begin{array}{c}\text { Work } \\
\text { not } \\
\text { related } \\
\text { to math }\end{array}$ & \\
\hline $\begin{array}{c}\text { Experienced } \\
\text { in ICT }\end{array}$ & & Abed & Salem \\
\hline $\begin{array}{c}\text { Moderately } \\
\text { experienced } \\
\text { in ICT }\end{array}$ & & Ameera & & Samar & \\
\hline $\begin{array}{c}\text { Poorly expe- } \\
\text { rienced in } \\
\text { ICT }\end{array}$ & Amef & & \\
\hline
\end{tabular}

of science for 12 years. Salem tried his best to post and comment on the non-math contributions to the three mathematical Facebook sites, but was not involved in the mathematical content of the sites. Towards the end of the course, Salem opened a Facebook site for his students about the cell phenomenon.

Abed: An experienced supervisor but moderately experienced in computers and the internet. Abed is 47 years old and has been a supervisor of mathematics in middle schools for ten years. Abed is moderately experienced in computers and internet. He had a negative image of the Facebook before participating in the course "Computers in education", considering it a social site for entertainment which may have negative consequences on the participants because they could get too much involved with unknown and harmful people.

When Abed participated in the three mathematical sites he got to know better the advantages of the communicational aspects of the Facebook, collaborating with the owners of the mathematical Facebook sites in order to improve their mathematical content, for example he collaborated with the sites' owners to post solutions of the mathematicians Al-Khwarizmi and Al-Khayyam for the quadratic and cubic equations respectively. When asked about the consequences of his active role in the Facebook sites he answered: "in a way, I felt like the owners of the sites, I felt I belong to what goes on in the three sites and should do my best to make the sites show the great mathematics of our past - Al-Khwarizmi and Al-Khayyam, and the mathematics of everyday life represented in the golden ratio.

As a supervisor, Abed suggested for his subordinate teachers to use the Facebook to communicate with other teachers, as well as to put mathematical questions in the Facebook for their students.

Samar: An experienced teacher in science, but moderately experienced in computers and internet. Samar is 33 years old and has been a middle school teacher of science for 11 years. Samar did not have a Facebook account at the beginning of the course, but expressed her willing to see how the Facebook could be integrated into education. At the beginning she was not active in any one of the three Facebook sites, but gradually she started to post and comment on the non-mathematical content of the sites. In the interviews, she said that the Facebook could be a good social companion of any course.

Amira: An experienced teacher in mathematics, but poorly experienced in computers and the internet including the Facebook. Amira is 38 years old and has been a high school teacher of mathematics for 15 years. At the beginning, she had hard time contributing to the three Facebook sites, but gradually she started to contribute her comments on the mathematical material posted there. At the end of the experiment, she said that the Facebook could be used to clarify mathematical ideas in an environment in which the students feel at home.

Aref: An experienced head of personnel in the ministry of education, but little experienced in computers and internet. Aref is 53 years old and has been the head of personnel in the ministry of education in his district for ten years. His characteristics are similar to those of Abed, but he is little experienced in computers and internet - working with Word only when needed and little involved with the internet. The consequences of Abed's and Aref's work 
in the Facebook have similarities as well as differences. Aref, after working actively in the three mathematical Facebook sites, decided to build by himself a mathematical Facebook page, where he started to put a mathematical quiz every week and discuss its solution with the friends.

We describe now the characteristics, conditions and Facebook educational work of the five moderately experienced educators (work experience more than five years and up to ten years).

Table II describes the division of the five educationally moderately experienced participants across their other characteristics.

Salam: She is 29 years old, a middle school mathematics teacher for 6 years. She is experienced in the ICT, and had already a Facebook account. She used the Facebook for keeping contacts with friends and relatives. At the beginning of the course she did not consider the Facebook a site suitable for mathematics education. Her contribution to the Facebook mathematical sites was moderate along the whole course. Her comments and posts were short but focused. They were social, as well as mathematical. In the interview she said that the Facebook is difficult to integrate in mathematics education because it does not enable to write mathematical symbols, but it may benefit students who are good in math and in computers, and who are able to write mathematical solutions, scan their hand-written solutions and upload them to the Facebook.

Amer: He is 27 years old, and has been a teacher of science in the middle school for 6 years. Amer is experienced in the ICT, and had at the beginning of the course a Facebook account. Amer participated extensively in the social and cultural talk happening at the three mathematical Facebook sites, but he participated little in the mathematical talk occurring there. At the interview he said he was not sure he would use the Facebook in his science classroom, but he would consider that in certain cases, for example at the end of the year when students are not seriously involved in learning.

Arij: She is thirty one years old, a ministry of education personnel, and has been working as such for 8 years; i.e. her work experience is moderate. She is mathematics department's graduate, but in the ministry of education, her work involves administration issues rather than mathematics education. She is experienced in computers and internet. Before participating in the course, Arij considered the Facebook a site for social life rather than education. Her participation and involvement in the Facebook mathematical sites were moderate, and she treated the social and cultural issues arising in the sites more than the mathematical content. Arij said that if she were a mathematics teacher whe would utilize the Facebook socially, culturally and historically in the mathematics classroom.

Soha: She is 32 years old, and has been a teacher of science for 8 years. Soha is experienced in the ICT in education, especially in using blogs and wikis. Soha did not have a Facebook account before participating in the course. She contributed very little to the Facebook mathematical sites. In the interview she considered the Facebook not suitable for education, saying that wikis are far more beneficial to science education than the Facebook.

Onsi: He is thirty years old. Onsi is a teacher of science for 9 years. His experience in computers and internet is poor. $\mathrm{He}$, as Soha, contributed very little to the Facebook mathematical sites. In the interview he described the Fa- cebook as a site where he would socialize with his students to try to encourage them to be active in his science classroom.

We describe now the characteristics, conditions and Facebook educational work of the four little experienced educators (work experience not more than five years).

Table III describes the division of the four educationally little experienced participants across their other characteristics.

Aseel: Aseel is 23 years old and has been a teacher of science in the middle school for two years. She is an experienced user of computers and internet and has had a Facebook account for two years. Aseel was very active in the social and cultural talk occurring in the three sites but little involved with the mathematical content there. In the interview Aseel expressed her willing to integrate the Facebook in her science teaching next year after preparing learning materials for science and which fit the Facebook like videos and images.

Rawan: Rawan is twenty four years old, has a first degree in Chemistry, and does not work as a teacher yet. She described herself as experienced in working with the Facebook for communicational and social goals. She said that the course opened her eyes how to utilize the video and images uploading option in the Facebook for teaching Chemistry; a subject whose teaching needs images and

TABLE II.

THE EDUCATIONALLY MODERATELY EXPERIENCED PARTICIPANTS

\begin{tabular}{|c|c|c|c|c|c|}
\hline \multirow{2}{*}{} & \multicolumn{2}{|c|}{ Teachers } & \multicolumn{3}{c|}{ Not teachers } \\
\cline { 2 - 6 } & $\begin{array}{c}\text { Math } \\
\text { majors }\end{array}$ & $\begin{array}{c}\text { Non-math } \\
\text { majors }\end{array}$ & \multicolumn{2}{|c|}{ Math majors } & $\begin{array}{c}\text { Non- } \\
\text { math } \\
\text { majors }\end{array}$ \\
\cline { 3 - 6 } & & Amer & $\begin{array}{c}\text { Work } \\
\text { related } \\
\text { to math }\end{array}$ & $\begin{array}{c}\text { Work } \\
\text { not } \\
\text { related } \\
\text { to math }\end{array}$ & \\
\hline $\begin{array}{c}\text { Experienced } \\
\text { in ICT }\end{array}$ & Salam & Arij & Soha \\
\hline $\begin{array}{c}\text { Moderately } \\
\text { experienced } \\
\text { in ICT }\end{array}$ & & Onsi & & & \\
\hline $\begin{array}{c}\text { Poorly expe- } \\
\text { rienced in } \\
\text { ICT }\end{array}$ & & & & & \\
\hline
\end{tabular}

TABLE III.

THE EDUCATIONALLY LITTLE EXPERIENCED PARTICIPANTS

\begin{tabular}{|c|c|c|c|c|c|}
\hline \multirow{2}{*}{} & \multicolumn{2}{|c|}{ Teachers } & \multicolumn{3}{c|}{ Not teachers } \\
\cline { 2 - 6 } & $\begin{array}{c}\text { Math } \\
\text { majors }\end{array}$ & $\begin{array}{c}\text { Non-math } \\
\text { majors }\end{array}$ & \multicolumn{2}{|c|}{ Math majors } & $\begin{array}{c}\text { Non- } \\
\text { math } \\
\text { majors }\end{array}$ \\
\cline { 3 - 6 } & & Aseel & $\begin{array}{c}\text { Work } \\
\text { related } \\
\text { to math }\end{array}$ & $\begin{array}{c}\text { Work } \\
\text { not } \\
\text { related } \\
\text { to math }\end{array}$ & \\
\hline $\begin{array}{c}\text { Experienced } \\
\text { in ICT }\end{array}$ & Salam & & & Rawan \\
\hline $\begin{array}{c}\text { Moderately } \\
\text { experienced } \\
\text { in ICT }\end{array}$ & & & & & \\
\hline $\begin{array}{c}\text { Poorly expe- } \\
\text { rienced in } \\
\text { ICT }\end{array}$ & Sofyan & & & & \\
\hline
\end{tabular}


videos, for example to show the movement of the electrons and protons in the atom. Rawan added that the Facebook could be utilized to strengthen the social relations between teachers and students, which could affect positively students' learning. Rawan remarked that the Facebook is a multimodal environment for its ability to integrate texts, images, videos, 'likes', links, etc. Regarding her activity, Rawan said that being not expert in mathematics she could not be as active as others in the three mathematical sites, but would be very active were the sites about Chemistry.

Salam: She is 25 years old and has been a physics teacher in the high school for three years. Salam was moderately experienced in computers and the internet. She participated moderately in the social and cultural talk occurring in the Facebook educational sites, while she was not involved at all in the mathematical content in the sites. In the interview, Salam expressed her doubt of the use of the Facebook in the high school physics classroom due to the pressure on high school teachers to finish the materials required from the students for the state exams.

Sofyan: He is 24 years old and has been a teacher in the middle and high schools for a couple of years. When he was introduced to the Facebook during the course, all what he knew about it was its being a site associated with chat and love affairs. He was neither active in the social and cultural talk occurring in the mathematical three sites, nor involved in the mathematical content of the sites. When asked about his activity in the Facebook sites he linked his little activity to his hard work as a new teacher, saying that the very active persons were not teachers but working in the headquarters of the ministry of education, and thus had time to participate actively in the Facebook sites. Sofyan also linked his little activity in the mathematical Facebook sites to his little experience in computers and the internet. Sofyan expressed his awareness of the educational advantages of the Facebook like uploading educational videos, as well to the educational disadvantages of the Facebook like making students distracted from their study when finding friends online.

\section{DISCUSSION}

Figure 1 summarizes the educational work of all the fifteen participants in the Facebook sites according to the grounded theory model.

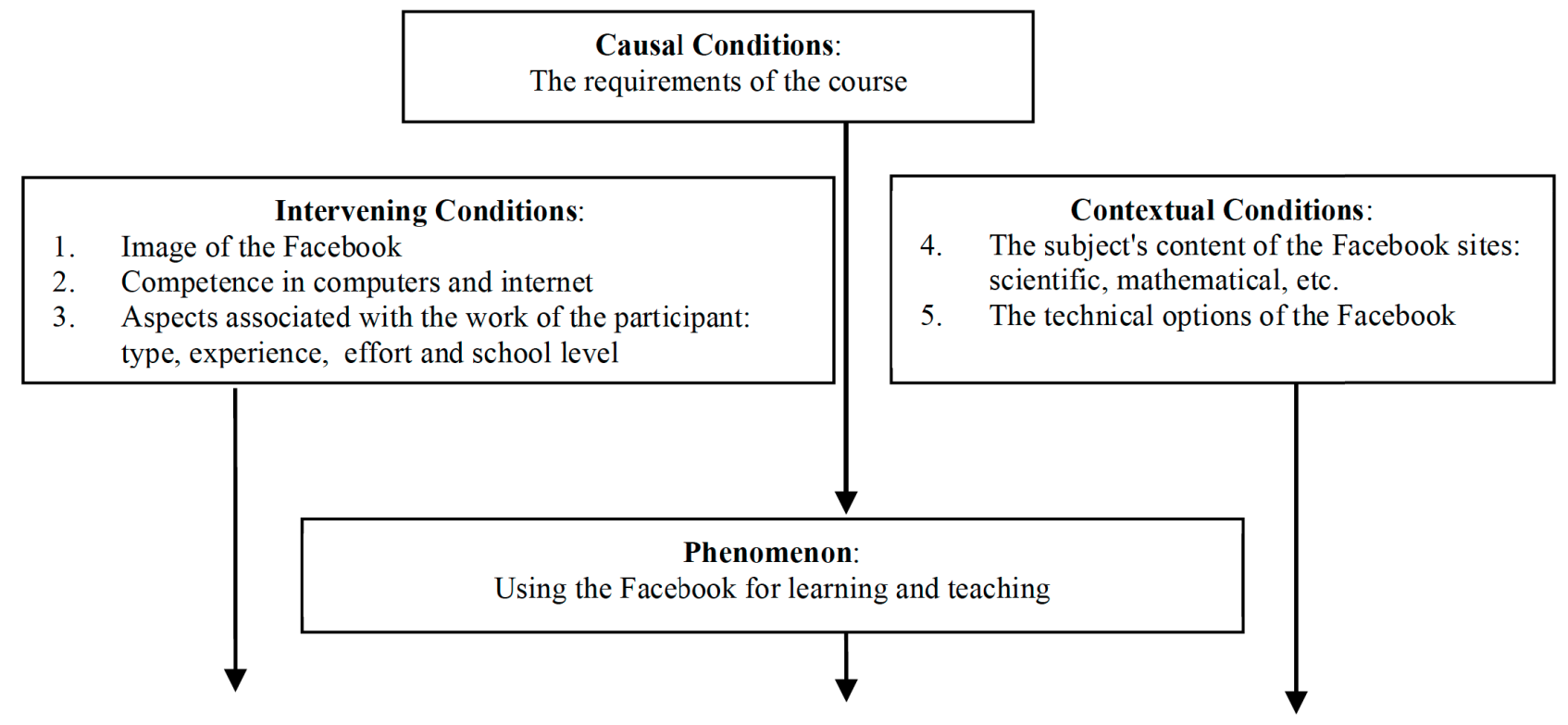

\section{Actions/ interactions:}

- Active/moderately active/little active in the social and cultural talk occurring in the Facebook sites

- Active/moderately active/little active in the mathematical content of the Facebook sites

- Utilizing/ not utilizing the Facebook technical options of the Facebook.

- Collaborating/ not collaborating with the owners of the Facebook owners

Consequences:
- Putting conditions on utilizing the Facebook in Education
- Being aware of the advantages, as well as the disadvantages of the Facebook
- Discovering how to utilize the Facebook for education

Figure 1. The educational work of the participants 
It was the aim of this research to find the conditions and consequences of working in the Facebook educationally. We distinguished, depending on the grounded theory, among three types of conditions which influence students/teachers/supervisors use of the Facebook. Below is a discussion of these conditions which influenced the educational work of the fifteen research participants in the Facebook environment.

\section{Causal conditions:}

What caused all the participants to work educationally in the Facebook? It was mainly the course's requirement. It had never occurred to any of them to think about the possibility of working educationally in the Facebook environment. So, the course was an opportunity for them to look at a tool not originally intended for education as an educational tool. This had probably opened their eyes at the educational potentialities possible in every tool, especially those available for all or at least for the students.

\section{Intervening conditions:}

The intervening conditions were:

1. The participant's image of the Facebook: this image could be described as a continuum starting from a very negative image to a very positive image, as described in Figure 4 below:

\section{$\longleftrightarrow$

$\begin{array}{cc}\text { A very } & \text { A very } \\ \text { negative } & \text { Positive } \\ \text { image } & \text { image }\end{array}$

Figure 2. The participant's Facebook image

Those who have negative image of a tool would probably not think at it as a possible educational tool. They need a starter which leads them to do so, in our case this starter constituted of the course's requirements. This image changed positively after students worked educationally in the three mathematics Facebook sites.

This image also includes the social aspect of the facebook; i.e. whether the student looks at the Facebook as a site for senseless chat or a site for socializing with old friends.

The individual participant's image of the Facebook is influenced by the public image of social networks which is characterized sometimes by negative visualization, for example it can be characterized by "puzzled dismay regarding a generation that, supposedly, has many friends but little sense of privacy and a narcissistic fascination with self-display" [21]. The individual participant's image of the Facebook is also influenced by his/her previous experience with the social networking site, for example Rawan did not have a negative image of the Facebook because she had already had a Facebook character, so she was at the beginning more opened to its use in education.

2. The participant's work: this condition has four dimensions: the participant's type of educational job, the participant's work specialty, the participant's experience in job and the participant's work effort.
The participant's type of educational job had three values in our case: a teacher, a supervisor and a head of personnel in the ministry of education. The participant's work specialty had two values in our case: math specialty and science specialty. The participant's job experience had three values in our case: not yet an educator, a new educator and an experienced educator, while the participant's work effort had two values in our case: hard work and 'not hard' work. Following is a discussion how the four dimensions interact to influence the participant's educational work in the Facebook.

Being an experienced teacher led two participants to transit their experience to their students, while being an experienced head of personnel in the ministry of education led another participant to open a personal page in the Facebook for weekly mathematical quizzes. Further, being an experienced supervisor led a third participant to suggest the Facebook as an environment for teachers' communication and usage. So, being an experienced educator in the discipline encouraged advanced utilization of the new technological environment or made the participants think of future advanced utilization of the new environment in their work. This results agree with previous researches' results that indicate the influence of experience on teachers' behavior, for example Ref. [22] found that teaching experience was one of the factors influencing the teacher's decision to continue teaching in the same district the following year. In addition, Ref. [23] found that the experiences of student teachers during a course changed their negative attitudes towards computers and assisted them in developing confidence in their use of ICT, in developing new perspectives about integrating ICT in mathematics education, and in developing appreciation for methods that foster students' learning. These findings of Ref. [23] are true in our reported experiment too, where the participants changed their negative perception of the Facebook as an educational tool and the experienced ones among them developed new perspectives regarding the Facebook use in mathematics and science education.

The participant's work specialty had also influenced the Facebook educational work of the participant. Participants whose specialty was were scarcely involved in the mathematical content of the Facebook sites, even if they were experienced users of the Facebook like Rawan. So, the participant's work specialty has a definite influence which overcame other factors' influences, on the participant's work in an educational electronic environment.

Another factor that influenced the Facebook educational actions/interactions of the participants is their work effort, as Sofyan claimed. Having a hard work lessened the activity of the participants in the Facebook and turned it to peripheral: watching others' activity, giving 'likes' and asking questions, while having a less hard work made some participants very educationally active in the Facebook: posting, commenting, solving problems and monitoring the actions/ interactions in the sites. Probably this factor does not work solely but together with the other three factors associated with the participant's work.

The previously described influence of the participants' work dimensions on his/her educational participation in the Facebook is desbribed in Figure 3. 


\begin{tabular}{|c|c|c|c|}
\hline \multirow{6}{*}{ 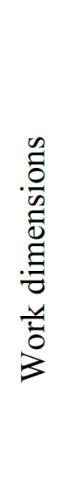 } & $\begin{array}{l}\text { The job } \\
\text { type }\end{array}$ & \multirow{6}{*}{ 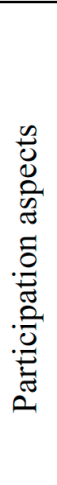 } & $\begin{array}{l}\text { The extent of } \\
\text { participation }\end{array}$ \\
\hline & \multirow{2}{*}{$\begin{array}{l}\text { The work } \\
\text { specialty }\end{array}$} & & \\
\hline & & & \multirow{2}{*}{$\begin{array}{l}\text { The type of } \\
\text { participation }\end{array}$} \\
\hline & \multirow[t]{2}{*}{$\begin{array}{c}\text { Job } \\
\text { experience }\end{array}$} & & \\
\hline & & & The \\
\hline & Work effort & & participation \\
\hline
\end{tabular}

Figure 3. Influence of work dimensions on participation aspects

3. Competence in computers and the internet: Competence in computers and the internet influenced the work of the participants in the Facebook, where it influenced the Facebook work of the experienced educators at the beginning only, while it influenced the work of the new educators all along their course experience. Aref who was comparatively week in computers and internet had hesitated steps at the beginning of his Facebook experience, but he had certain steps towards the end of the course. On the other hand, Sofyan who was week in computers and the internet and at the same time a new teacher had peripheral educational participation in the Facebook all along his course experience. It could be claimed that here too, not only the competence in computers and internet influenced the participant's educational work in the Facebook, but also their work experience, where the work experience compensated for the little competence in computers and the internet and assisted the participants towards overcoming their little competence. The influence of competence in computers and the internet on the participants' work in the Facebook is supported in previous researchers, where lack of ICT competence and lack of ICT confidence influenced negatively teachers' use of new media in the classroom [24].

\section{The contextual conditions were:}

1. The content of the site subject: the mathematical sites' subjects (historical mathematicians and mathematical phenomena) made the participants enthusiastic to participate in them because, on one hand, the participants were connected to the mathematicians by heritage - being all muslims, and, on the other hand, the golden ratio was connected to the students through its relation to real life, art, and the students own bodies. The influence of the heritage connection on students' feelings is mentioned in Ref. [25] who found that the preservice teachers' work in projects which connected them to their heritage made the students view their work as fun, as something that benefits them and as something that makes them proud of their mathematical heritage. Further, they found that this experience encourages the preservice teachers to use such projects in their future teaching.

2. The technical options: these options were of two types: restrictive and assistive. Examples on the restrictive options are: the inability to upload Microsoft Office files and the inability to write mathematical symbols in the Facebook. These inabilities lessened the activity of the participants because the inabilities restricted their mathematical action. The participants tried to find alternatives for these inabilities, for example they wrote the mathematical equations by hand, took pictures of them, and then uploaded the solutions as pictures to the Facebook. Examples on the assistive options are: the ability to upload videos and pictures, the ability to express 'liking' something, the ability to post a text, the ability to ask a question, etc. These assistive options were behind the participants' new awareness of the Facebook fitness as an educational too.

The previous findings agree with researches which emphasized the importance of environmental factors on the adoption and diffusion of ICT (for example Ref. [26]). Among these environmental factors are the technology characteristics that the current research points at as influencing students' adoption of the Facebook as an educational environment.

\section{Actions/interaction of the participants:}

There were three levels of educational participation in the Facebook: peripheral participation, moderate participation and high participation. The level of participation was influenced, as described above, by the intervening conditions associated with every participant. These conditions also influenced the type of participation; i.e. the way the participants collaborated with the Facebook sites' owners and how they contributed to the teaching and learning of mathematics in the sites - whether they initiated learning actions like showing a historical method of solving mathematical equations, whether they commented on mathematical content, etc. Being an experienced educator resulted in more mathematical actions, while being a new educator resulted mainly in watching the uploaded videos and images which included mathematical content. On the other hand, being an experienced user of computers and the internet resulted in more utilization of the Facebook options (posts, comments, likes, etc.) and utilization of other technological options (taking images of mathematical solutions, uploading the image to the Facebook site, etc.). Sometimes, not being experienced in the use of computers and the internet resulted in collaboration with the sites' owners who helped the participants show their mathematical work. This collaboration meets the characteristics of successful collaboration described by Ref. [27], for example being voluntary and being based on mutual goals. These goals are, in our case, using the Facebook for mathematics learning and specifically presenting historical solutions of mathematical equations.

Consequences of working educationally in the Facebook environment:

These consequences were varied, starting from discovering how to utilize the Facebook for mathematics education and being aware of the advantages/ disadvantages of the Facebook, to proceeding with the use of the Facebook in contexts other than those suggested in the course. Niess (2005) described four different aspects that comprise teachers' TPACK: An overarching conception of teaching with technology; knowledge of instructional strategies and representations for teaching with technologies; knowledge of students' understandings, thinking, and learning with technology; and knowledge of curriculum and curriculum 
materials that integrate technology with learning. All the participants in the current research experienced the four aspects of TPACK. They had a general conception of what it means to teach mathematics with the Facebook: integrating videos and pictures of mathematics solutions but not being able to write mathematical symbols; they all witnessed how the sites' owners used instructional strategies to motivate the 'friends' to learn mathematics; for example tagging the friends in the posted videos or pictures, adding 'like' to the friends contributions, etc.; they all experienced multimodal presentations and problem solving as aspects of learning mathematics in the Facebook sites' and all of them witnessed mathematics history and phenomena come alive in a social networking site. Some of them even used and suggested the Facebook to be used in contexts other than those witnessed.

As discussed above, the consequences of the educational work in the Facebook were influenced by the various conditions associated with the experiment (causal, intervening and contextual), in addition to the actions/interactions with which the participant was involved. Participants who had peripheral participation did not proceed with Facebook educational actions outside of the initial context, while participants who had high Facebook educational participation proceeded to new contexts trying to adjust mathematics education to the new technological social environment. This educational action was influenced by conditions other than the level of participation, for example they were also influenced by the educational work of the participant and the participant's work experience.

\section{CONCLUSIONS}

In the reported experiment, the Facebook was suggested for teaching and learning mathematics through sites of historical mathematicians and mathematical phenomena. This was done in the frame of a second degree course "computers in education" which emphasized the educational aspects of web 2.0 tools. Various conditions affected the teachers/students work in the Facebook educational sites: causal conditions, intervening conditions and contextual conditions. One causal condition made the students participate in the Facebook educational sites: the course's requirement. There were three intervening conditions: the participant's image of the Facebook, the participant's work characteristics and the participant's competence in computers and internet. The contextual conditions were: the site's subject and the environment's characteristics or conditions. These conditions influenced the students' actions and interactions in the Facebook educational sites, especially their level of participation which had three values: peripheral, moderate and high. The actions/interactions of the participants, in addition to the conditions influencing these actions/interactions, influenced the consequences of their work in the Facebook educational sites. These consequences were varied, starting from discovering how to utilize the Facebook for mathematics education and being aware of the advantages/ disadvantages of the Facebook, to proceeding with the use of the Facebook in contexts other than those being suggested in the course.

\section{REFERENCES}

[1] Anderson, P. (2007). What is Web 2.0? Ideas, technologies and implications for education. JISC, Technology and Standards Watch. http://citeseerx.ist.psu.edu/viewdoc/download?doi=10.1.1.108.999 $\underline{5 \& \text { rep }=\text { rep } 1 \& \text { type }=\text { pdf }}$

[2] Carr, N. (2008). Wikis, knowledge building communities and authentic pedagogies in pre-service teacher education. In Hello! Where are you in the landscape of educational technology? Proceedings ascilite, Melbourne 2008. http://www.ascilite.org.au/con ferences/melbourne $08 /$ procs/carr-n.pdf

[3] McLoughlin, C. \& Lee, M. (2007). Social software and participatory learning: Pedagogical choices with technology affordances in the Web 2.0 era. In ICT: Providing choices for learners and learning.Proceedings ascilite, Singapore 2007.

[4] Littrell, A. B. (2005). "My Space": Using blogs as literature journals with adolescents. Unpublished dissertation, Tennessee Technological University, Cookeville.

[5] Daher, W. (2010). Wiki Interaction Tracks in Geometry Learning. International Journal of E-Adoption, 2 (4), 15-34. http://dx.doi.org/10.4018/jea.2010100102

[6] Forte, A., \& Bruckman, A. (2007). Constructing text: Wiki as a toolkit for (collaborative?) learning. http://www.wikisym.org/ ws2007/ publish/Forte WikiSym2007 ConstructingText.pdf

[7] Grant, L. (2006). Using Wikis in Schools: a Case Study. http://www.futurelab.org.uk/resources/documents/discussion pape rs/Wikis in Schools.pdf

[8] Nielsen, L. (2010). 8 real ways facebook enriched Ms. Schoening's first grade class. Tech \& Learning, September, 22, 2010. http://www.techlearning.com/article/Blogs/33030

[9] Madge, Clare, Meek, Julia, Wellens, Jane \& Hooley, Tristan (2007), Facebook, social integration and informal learning at university: 'It is more for socialising and talking to friends about work than for actually doing work', Learning, Media and Technology, 34: 2, pp. 141-155. http://dx.doi.org/10.1080/ 17439880902923606

[10] Fischman, J. (2008, October 13). Dear Professor, students want to chat with you. The Chronicle of Higher Education. Retrieved October 15, from http://chronicle.com/wiredcampus/article/3384/ dear-professor-

[11] Hewitt, A. \& Forte, A. (2006). Crossing boundaries: Identity management and student/faculty relationships on the Facebook. Presented at the Computer Supported Cooperative Work Conference, Banff, Alberta, Canada.

[12] Munoz, C. \& Towner, T. (2009). Opening Facebook: How to Use Facebook in the College Classroom. In I. Gibson et al. (Eds.), Proceedings of Society for Information Technology \& Teacher Education International Conference 2009 (pp. 2623-2627). Chesapeake, VA: AACE.

[13] English, R. \& Duncan-Howell, R. (2008). Facebook $\odot$ Goes to College: Using Social Networking Tools to Support Students Undertaking Teaching Practicum. MERLOT Journal of Online Learning and Teaching, 4 (4), 596-601.

[14] Mazer, J. P., Murphy, R.E., \& Simonds, C.J. (2007) 'I'll see you on "Facebook": The Effects of Computer-Mediated Teacher SelfDisclosure on Student Motivation, Affective Learning, and Classroom Climate'. Communication Education, 56:1, 1-17. http://www.ascilite.org.au/conferences/singapore07/procs/mcloug hlin.pdf http://dx.doi.org/10.1080/03634520601009710

[15] O'Sullivan, P. B., Hunt, S. K., \& Lippert, L. R. (2004). Mediated immediacy: A language of affiliation in a technological age. Journal of Language and Social Psychology, 23, 464-490. http://dx.doi.org/10.1177/0261927X04269588

[16] Blattner, and Fiori (2009). Facebook in the Language Classroom: Promises and Possibilities. International Journal of Instructional Technology and Distance Learning, 6 (1), 17-28.

[17] Kabilan, M. K.; Ahmad, N. \& Zainol-Abidin, M. J. (2010). Facebook: An online environment for learning of English in institutions of higher education? The Internet and Higher Education. http://dx.doi.org/10.1016/j.iheduc.2010.07.003

[18] Nielsen, L. (2010, September, 22). 8 real ways facebook enriched Ms. Schoening's first grade class. Tech \& Learning. http://www.techlearning.com/article/Blogs/33030

[19] Strauss, A., \& Corbin, J. (1998). Basics of qualitative research: Techniques and procedures for developing grounded theory (2nd ed.). Thousand Oaks, CA: Sage. 
[20] Baya'a, N. \& Daher, W. (2010). Middle school students' learning of mathematics using mobile phones: Conditions and consequences. Journal of Interactive Learning Research, 21(1), 1-25.

[21] Livingstone, S. (2008). Taking risky opportunities in youthful content creation: teenagers' use of social networking sites for intimacy, privacy and self-expression. New media \& society, 10 (3), 393-411. http://dx.doi.org/10.1177/1461444808089415

[22] Theobald, N.D. (1990). An Examination of the Influence of Personal, Professional and School District Characteristics on Public School Teacher Retention. Economics of Education Review, 9 (3), 241-250. http://dx.doi.org/10.1016/0272-7757(90)90005-P

[23] Ponte, J. \& Oliveira, H. (2002). Information technologies and the development of professional knowledge and identity in teacher education. In J. Novotná (Ed.), Proceedings of II European Conference in Mathematics Education (CERME), 310-321. Praga: Univerzita Karlova v Praze, Pedagogická Faculta.

[24] Totter, A., Stutz, D., \& Grote, G. (2006). ICT and schools: Identification of factors influencing the use of new media in vocational training schools. The Electronic Journal of e-Learning, 4 (1), 95102.

[25] Daher, W. \& Baya'a, N. (2011). Building Multimedia and Web Resources for Teaching Mathematical Concepts through their His- torical Development. In G. Styliaras, D. Koukopoulos and F. Lazarinis (Eds.), Handbook of Research on Technologies and Cultural Heritage: Applications and Environments, 370-391. IGI Global.

[26] Kwon, T. \& Zmud, R. (1987). Unifying the Fragmented Models of Information Systems Implementation, in Hirshheim (Ed.), Critical Issues in Information Systems Research. NY: John Wiley \& Sons.

[27] Friend, M., \& Cook, L. (1992). The new including: How it really works. Instructor, 101(7), 30-36.

[28] Niess, M.L. (2005). Preparing teachers to teach science and mathematics with technology: Developing a technology pedagogical content knowledge. Teaching and Teacher Education, 21, 509523. http://dx.doi.org/10.1016/j.tate.2005.03.006

\section{AUTHOR}

W. Daher is with An-Najah National University, Nablus, Palestine and with Al-Qasemi Academic College of Education, Baqa, Israel (wajeehdaher@gmail.com).

Submitted 28 March 2014. Published as re-submitted by the author 26 May 2014. 